\title{
The Physiologus and the Apocryphal Acts of the Apostles
}

\begin{abstract}
Animals play prominent roles in the apocryphal acts of the apostles, and the authors of these texts seem to have drawn on natural historical information similar to what is found in the Physiologus. Nevertheless, the relationship between the acts and the Physiologus is complicated and often puzzling. There is at least one instance in which the apocryphal acts (the Acts of Thomas) clearly presuppose information about an animal (the wild ass) also presented in the Physiologus, as well as two instances in which the Physiologus refers to a character from the apocryphal acts (Thecla). Otherwise, the most striking result of comparing the acts with the Physiologus is the absence of clearly coinciding material. Relatively few animals occur in both the Physiologus and the acts, and, when they do, there is little, if any, overlap in content. This paper will detail the points of contact between the Physiologus and the apocryphal acts, as well as the absence of contact where such could easily be imagined. Ultimately, I will show that the Physiologus and the apocryphal acts of the apostles exhibit a similar attitude toward the natural world and the use of similar source material, but the exact relationship between these texts remains obscure.
\end{abstract}

\section{Introduction}

I first encountered the Physiologus when writing my dissertation on animals in the apocryphal acts of the apostles. When searching the Thesaurus Linguae Graecae for other accounts of bedbugs, snakes, talking dogs, licentious partridges, friendly lions and the other various animals that populate the apocryphal acts, I continually stumbled upon the Physiologus (along with the works of Aelian, Oppian, Antigonus of Carystus, Phlegon of Tralles, Apollonius the paradoxographer, and other authors that I hadn't ever heard of-but some of which were so interesting that they have now become my research focus). At the time, my interest was in understanding the apocryphal acts, not the Physiologus, and I was not particularly interested in investigating the relationship-if any-between any of the apocryphal acts and the Physiologus. I have since grown more interested in the Physiologus for its own merits. However, reading through much of the modern scholarship on the Physiologus, particularly the arguments concern- ing the date of its composition and its religious milieu, ${ }^{1}$ it occurred to me that a more careful consideration of the text alongside the apocryphal acts, particularly the Acts of John, Acts of Paul, and Acts of Thomas ${ }^{2}$ might have something new to offer. What I have found is fewer direct connections than I might have imagined, but, nevertheless, a shared perspective on the natural world that is, in my opinion, well worth noting.

In what follows, I will first evaluate proposed connections between the Physiologus and the Acts of Paul (more precisely, the Acts of Paul and Thecla), the Acts of John and the Acts of Thomas. The first two are connections that have been noticed and discussed by others, the third is my own proposal. From there I will turn to a consideration of broader similarities in these texts' apparent attitudes towards the natural world and, above all, the animals within it.

\section{The Acts of Paul and Thecla and the Physiologus}

The clearest connection of the Physiologus with the apocryphal acts is the mention of Thecla in chs. 17 and 40. In c. 17, which describes the aspidocelone, a big fish that attracts little fishes with the sweet smell of its mouth and swallows them, whereas the mature fish know better than

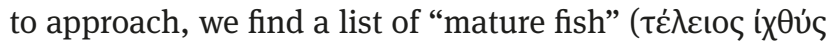
in the G manuscript; including also the phrase toù $\delta \dot{\varepsilon}$

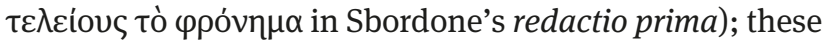
"mature fish" include Moses, Isaiah, Jeremiah and all the prophets, Judith, who escaped Holophernes, Esther, who escaped Artaxerxes, Susannah, who escaped the elders,

\footnotetext{
1 Is it a product of the $4^{\text {th }}$ century CE (as, for example, Wellman and Scott have argued) or of the $2^{\text {nd }}$ century (as, for example, Perry and Treu have maintained)? Is it "gnostic" (as Treu contends) or is it orthodox (as Perry believed)? See Wellmann (1930), Scott (1998), Perry (1941), and Treu (1966).

2 In Animals in the Apocryphal Acts of the Apostles (Spittler 2008) I argue that the Acts of John, Acts of Paul, Acts of Peter, and Acts of Thomas share an interest in the natural characteristics of animals and a positive evaluation of the natural world, whereas the Acts of Andrew and Acts of Philip (the "exceptions that prove the rule") espouse a more negative evaluation of animals and the natural world or a lack of interest, respectively. In what follows, when referring to the "apocryphal acts of the apostles" as a group, I am referring to the Acts of John, Acts of Paul, Acts of Peter, and Acts of Thomas.
} 
and, finally, Thecla, who escaped Thamyris. In c. 40, a rather odd chapter describing the ibis, ${ }^{3}$ we find Thecla again. Here, she is listed among individuals who are saved by making the sign of the cross with their own bodies; these include Moses, Daniel, and Jonah, followed by the same list of women found in c. 17, now in almost reversed order (Thecla, Susannah, Judith, and Esther). Here we find a longer report on Thecla: according to the $\mathrm{G}$ manuscript, Thecla conquered "fire and beasts, and was saved by faith"

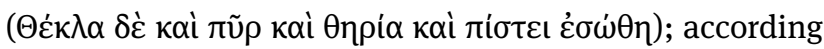
to Sbordone's redactio prima "Thecla was cast into fire and to beasts and seals, and the figure of the cross saved

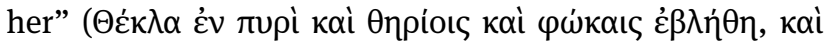

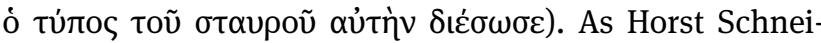
der has noted, both versions are compatible with the text of the Acts of Paul and Thecla, in which Thecla "having

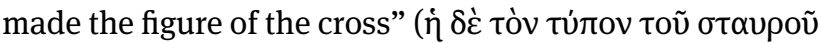

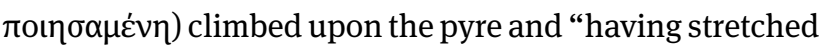

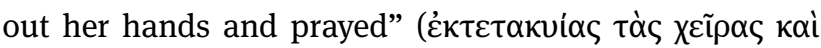

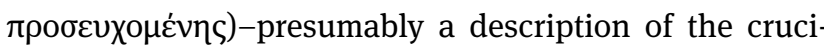
form orans pose-baptized herself in a pool of seals in the course of a beast fight. ${ }^{4}$ Schneider correctly concludes that the author of these passages had the text of the Acts of Paul and Thecla before him, inasmuch as the details correspond so closely. ${ }^{5}$ Moreover, these details cannot have derived from the most popular images of Thecla (e.g. on pilgrim flasks from the cult site of St. Menas) in which, contra the written text of the Acts of Paul and Thecla and the description in the Physiologus 40, Thecla is depicted with arms bound behind her. ${ }^{6}$

As Schneider has suggested, it is quite possible that the reference to Thecla in c. 40 is an interpolation; in Sbordone's redactio prima the syntax pairs her with Jonah, but then leaves Jonah grammatically dangling. When, however, the two phrases involving Thecla are removed, the syntax flows smoothly. ${ }^{7}$ If Thecla is indeed an interpo-

3 On the ibis chapter see Schneider (2002a).

4 Schneider (2002a, 161).

5 Schneider (2002a, 161).

6 See discussion by Castelli (2004, 166-167). Note, however, that in the apparently earliest visual depiction of Thecla, in a mid-fourth century burial chamber in Thessaloniki, she is depicted in the cruciform orans pose (See discussion in Castelli 2004, 159-162). Is it possible that early (largely not extant) images of Thecla depicted her in the orans pose, whereas later images moved away from the text's written image, depicting her instead with arms bound? Could this help us in dating the reference to Thecla in the Physiologus 40?

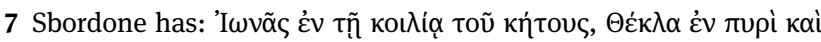

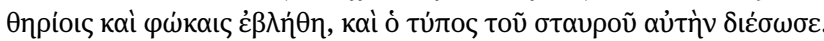

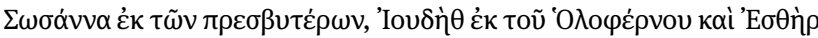

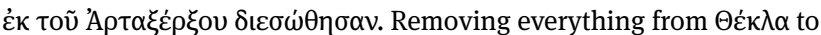

lation in c. 40, however, I think Schneider's suggestion, "daß die Erwähnung des Thekla-Exempels in Kapitel 17 die Interpolation in Kapitel 40 provoziert haben könnte,"8 is very likely correct. I do not see any reason to suspect that the mention of Thecla in c. 17 is not original; that said, because c. 17 mentions only the names Thecla and Thamyris, without any of the details found in c. 40, it could reflect a general familiarity with the Thecla narrative, rather than an author who has the text of the Acts of Thecla before him.

And indeed, as Alan Scott has written, "it is not surprising that the Physiologus refers to Thecla, not only because she was a popular figure but because the author of the Physiologus surely must have been interested in the fantastic stories about animals in these legends." 9 That is an entirely reasonable observation, but I cannot help but ask myself: why aren't there any seals in the Physiologus? ${ }^{10}$ Why not mention Thecla or, for that matter, Paul in the report on the lion in c. 1? In other words, I can imagine and even might expect more connections between the Physiologus and the Acts of Thecla than what we actually have.

\section{The Acts of John and the Physiologus}

Erik Peterson has suggested that the report in Sbordone's Physiologus 31a (concerning the three youths in the furnace) that the apostles moved mountains into the sea

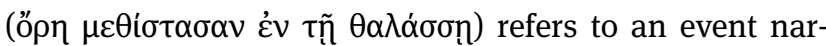
rated in the Acts of John. ${ }^{11}$ No such episode is found in the extant Acts of John, but Theodore the Studite, in an oration on Saint John, includes a list of miracles performed by him, including moving a mountain into the water (opos

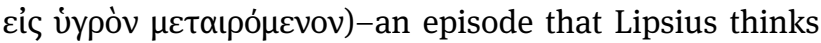

$\overline{\delta \text { เ̇́} \sigma \omega \sigma \varepsilon}$ would clearly improve the syntax; that said, it would also

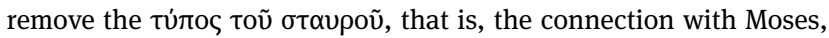
Daniel and the primary content of the chapter. A look at the variants only complicates the situation. As noted above, $\mathrm{G}$ also lacks any reference to the form of the cross; it also lacks mention of Judith and Esther. $\Sigma, \mathrm{O}, \mathrm{s}$ and $\mathrm{W}$ include Thecla and the form of the cross, adding also the three youths in the furnace; A, I and E include only the initial example of Moses (see Kaimakis 1974, 114a-115b).

8 Schneider (2002a, 163).

9 Scott (1998, 437-438).

10 For evidence that there was plenty of material to work with, had the author of the Physiologus wanted to include seals, see Horst Schneider's excellent article "Thekla und die Robben" (2001).

11 Peterson $(1959,236)$. 
was drawn from the original Acts of John. ${ }^{12}$ Given the fragmentary state of the Acts of John, this is entirely possible; in fact, Lipsius takes Theodorus' list of miracles performed by John as evidence of how little of the oldest form of the Acts of John is extant. ${ }^{13}$ Lipsius may well be right in assigning an episode involving the moving of mountains to the Acts of John. After all, John does bring down half of the temple of Artemis in Ephesus in c. 42-a comparable feat. But while plausible, it remains far from certain that the Physiologus refers to the Acts of John in c. 31a.

It is equally difficult to establish a clear connection between the description of the partridge in Acts John 56-57 and the Physiologus 18. In the Acts of John the apostle marvels at a partridge fluttering and rolling in the dust-an activity that somehow scandalizes a certain priest who observes John's delight at the sight. The episode in the Acts of John seems to depend on the partridge's general reputation for bad behavior and lust (reported by Aristotle, Ps. Antigonus, Pliny, Plutarch, Aelian and others). The lustiness of the bird was so well-known, in fact, that Athenaeus can write "the animal is employed symbolically for lust" ( characteristic makes some sense of the priest's otherwise odd reaction: he is appalled to find the apostle delighting at the activities of a notoriously wicked and lascivious creature. In the Physiologus 18, we find a very different report, that is, that the partridge gathers and broods other birds' eggs, which will abandon the false parent once they hatch. This report is quoted from the LXX and is taken up also by Origen, ${ }^{16}$ but I find no hint of it in the partridge episode in

12 Lipsius (1883, 442-443). The text of Theodore the Studite is from Cod. Par. Gr. 1197.

13 Lipsius (1883, 442-443). Lipsius laments (443): "Von all diesen Wundergeschichten, mit Ausnahme der einen schon erwähnten, hat sich sonst keine Spur erhalten: wir ersehn hieraus zu unserm Bedauern deutlich, wie geringe Reste wir noch von den alten Johannesacten besitzen."

14 Acts of John 56-57 = Cod. Par. Gr. 1468v; see Junod and Kaestli (1983, 141-158, 373).

15 See discussion in Spittler (2008, 116-124).

16 The behavior described in LXX Jer 17:11 does not, to my knowledge, correspond to any reports concerning the partridge ( $\pi \varepsilon \dot{\rho} \delta\llcorner\xi)$ in Greek sources. The explanation of the report provided by the Physiologus seems, perhaps, to relate to ancient reports of the cuckoo

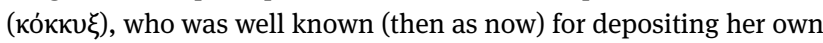
eggs in the nests of other species of birds. As Aelian writes, "when [the cuckoo's young] are fledged and recognize themselves as bastards, they fly away and set out for their [real] parent" (De natura animalium 3.30); perhaps the Physiologus, familiar with the cuckoo, has understood the partridge in Jer 17:11 as the bird on the receiving end of the cuckoo's egg deposit. Notably, Origen does not take this tack, instead satisfying himself with determining whether the partridge is the Acts of John. Likewise, the Physiologus makes no use of the lustiness of the partridge-thus I see no connection at all, at least as far as the partridge goes.

It is then plausible, though not at all certain, that the author of the Physiologus was familiar with either the text of the Acts of John or some of the stories therein. But if Peterson is correct in suggesting that the author of the Physiologus borrows from the Acts of John, then why not include the famous bedbugs from the Acts of John 60-61? Why is the partridge presented so differently? As with the Acts of Thecla, there are fewer connections than we might hope for.

\section{The Acts of Thomas and the Physiologus}

There is one instance in the apocryphal acts in which an author clearly indicates knowledge of a report on animal behavior also present in the Physiologus. In the Acts of Thomas act 8, we find an interesting episode involving wild asses: ${ }^{17}$ Thomas, travelling with a certain captain, on his way to help the man's wife and her daughter, both possessed by demons, has set out in a wagon drawn by typical beasts of burden (ن் exhausted and the wagon comes to a halt; seeing a herd of wild ass colts grazing near the road, he instructs the captain to go into the herd and tell the wild asses that "Judas Thomas the apostle of the Christ, the son of God," has need of their services. The captain is afraid, and well he should be: wild asses are dangerous creatures, according to the ancient natural historians. ${ }^{18}$ But these wild asses respond immediately and positively, competing for the honor of being yoked to Thomas' wagon, and, once yoked, pulling that wagon directly to the captain's house with no direction. When they arrive, Thomas commands one of the wild asses to enter the courtyard and call out the demons that have possessed the two women. The wild ass then enters the courtyard, opens his mouth and speaks-in fact say-

good or bad (and thus whether it should be understood as representing Christ or the devil). Turning to what the natural historical sources report about the partridge, including both it's general reputation for lust, and a specific behavior involving the deception of hunters, Origen concludes it must be interpreted as the devil. In all likelihood, Origen here depends on some version of Aristotle's Historia Animalium, which describes the partridge's deception of hunters and its general bad character at $613 \mathrm{~b}$.

17 See my more extensive discussion in Spittler (2008, 199-221). 18 See Aelian, De natura animalium 4.52; Oppian, Cynegetica 3.183207. 
ing much more than Thomas commanded. Moreover, after the apostle exorcises the demons-a process that leaves the women seemingly dead on the ground-the wild ass speaks up yet again, this time both scolding the apostle for his inaction and delivering something of a sermon, warning the crowds who have gathered about "false apostles and prophets of lawlessness" who "are not satisfied with one wife" but "destroy many women"; they "say one thing with their mouths, but they think another in their hearts," they "command others to keep away from fornication, theft and greed, but all these things-they live their lives in them, while teaching others not to do them."19

This is a strange episode, raising multiple questions, foremost in my mind being: why a wild ass? Why choose this particular animal to play this prominent role in the text, delivering this particular message? As I have argued elsewhere, the report on the wild ass in Physiologus 9 (reported also in Ps.-Aristotle's On Marvelous Things Heard, by Oppian and, of the African wild ass, by Pliny ${ }^{20}$ offers a clear answer:

Concerning the wild ass : It is written in Job, "who has set the wild ass free?" The Physiologus has said concerning the wild ass that he is the leader of a herd, and should any of the roaming females give birth to males, their father cuts all their genitals, so that they not produce seed. For the patriarchs sought to sow bodily seed, but the apostles, [to sow] noetic children, practiced encratism, seeking heavenly seed, as it is written, "be of good cheer, sterile woman who does not give birth; break out and shout, you who do not have birth pangs; for the children of the desert are more than those of the woman who has a husband." The old is the seed of promise; the new is of encratism. The Physiologus spoke well about the wild ass.

The behavior here described coordinates perfectly with the warning issued by the wild ass: male wild asses, according to the Physiologus, are indeed "not satisfied with one wife," and "destroy many women"; moreover, they "say one thing with their mouths"-quite literally with their castrating bite-while practicing just the opposite. Note that in the Acts of Thomas c. 70, the herd of wild asses are referred to explicitly as $\pi \dot{\omega} \lambda$ ot, ${ }^{21}$ "colts" or "young males"; according to the natural historians, these should be, then, a heard of eunuchs, grazing together in the desert. Who better to rail against the hypocrisy of false prophets who

19 Acts of Thomas 79.

20 Ps.-Aristotle, De mirabilibus auscultationibus 10; Oppian, Cynegetica 3.191-207; Pliny, Naturalis historia 8.46; cf. Solinus Collectanea rerum memorabilium 27.27.

21 Note, however, that there are variant readings of this word in manuscripts $\mathrm{U}$ and $\mathrm{V}$. engage in fornication? Who better to represent the encratic message of the Acts of Thomas?

It seems, then, that the author of the Acts of Thomas was well aware of the natural historical information on the wild ass reported in the Physiologus and elsewhere, but also conscious of the specific Christian meaning attached to these animals by the Physiologus. It is plausible that the Acts of Thomas, likely composed in a Greek-Syriac bilingual environment in the mid third century, is in fact literarily dependent on the Physiologus in this section. That said, of the two other animal-related episodes in the Acts of Thomas, one involves an animal not treated in the Physiologus (a domestic ass); the other, involving a love-sick, murderous snake, has no obvious connections to the Physiologus 10 or 11, where snakes are discussed..$^{22}$ Moreover, the well-known "hymn of the pearl" in the Acts of Thomas 108-113 shows no contact with the report on the agate and the pearl in the Physiologus $44 .^{23}$

\section{What do the apocryphal acts and the Physiologus have in common?}

While direct literary connections between the Physiologus and the apocryphal acts are slimmer than we might hopeor, perhaps I should say, slimmer than I had hoped-there are still strong connections in terms of interests and attitude toward the natural world. In what follows, I will discuss three common interests that I think are significant for understanding the overall aims of these texts.

22 Brief mentions of the eagle (in Acts of Thomas 91 and 111), the partridge (in Acts of Thomas 91), and the dove (in Acts of Thomas 91 and 50) have no contacts with the reports on these birds in the Physiologus 12,18, 28 or 35 (in any of its versions). Notably, the reference to the

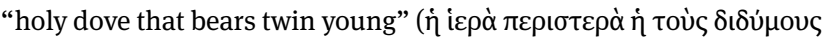

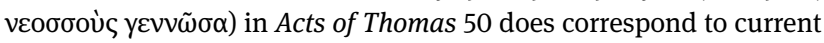
natural historical information, where it is reported that doves generally lay two eggs at a time and raise two chicks (see Aristoteles Historia Animalium 6.4.562b)

23 There is a minor point of contact in the mention of adamant in in Acts of Thomas 108 (at line 8 of the Hymn of the Pearl). The ex-

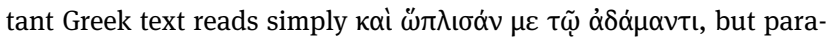

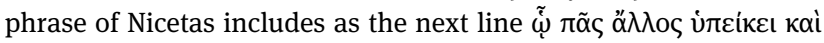

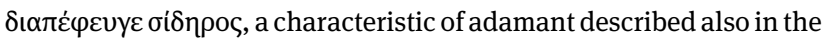
Physiologus 42. This, however, is easily the most well-known characteristic of a well-known stone (see, e. g., Pliny Naturalis historia 37.57), and so there is no reason to suspect that the author of the Hymn of the Pearl was dependent upon the Physiologus. 
1 The Physiologus and the apocryphal acts of the apostles share a strong interest in the particular characteristics of real animals

This point, I think, bears repeating-especially with respect to the animals described in the Physiologus-because the opposite is often at least implied by our own (that is, scholars') habits in describing the text. Take, for example, the first sentence of Wellmann's work on the Physiologus: he refers to the text with its "wunderbaren Geschichten vom Einhorn, Vogel Phönix, Pelikan, Ameisenlöwen," etc. Given that three of the four animals listed are, in the modern world, well-known mythical creatures, this description-though not the substance of Wellmann's work-leaves the impression that the Physiologus has little to do with real animals in the natural world. Ben Edwin Perry notes that the text describes both real and mythical creatures, but calls the characteristics described "fabelhaft." ${ }^{24}$ Ursula Treu writes that the Physiologus reads "more like fabulous stories than like specimens of zoological history." 25 Alan Scott describes the content of the Physiologus as "the exposition of fantastic beasts for moral purposes.” Patricia Cox Miller is more sympathetic to the complexities of the Physiologus, but nevertheless emphasizes the fabulous nature of the reports, writing: "if nature is a text, and if what the text gives to be read are images and likenesses of hidden realities, then of course the reading will yield fantastical creatures." ${ }^{26}$ Similarly, Otto Schönberger dismisses the importance any relationship between the animals described in the Physiologus and real animals in the real world, writing "es geht nicht darum, ob es das Einhorn wirklich gibt, sondern es kommt auf die rechtgläubige Erklärung seiner Bedeutung an."27

But the truth is that, even from a contemporary perspective, the vast majority of animals described in the Physiologus are real, not mythical, animals-the exceptions being the phoenix, sirens and centaurs, the ant-lion and unicorn. From an ancient perspective, not even all of these are clearly mythical: many clearly regarded the phoenix as a real, if exceedingly rare, bird $;^{28}$ the unicorn

24 Perry $(1941,1074)$.

25 Treu $(1993,198)$.

26 Cox Miller $(2001,65)$.

27 Schönberger (2001, 145-146).

28 Herodotus, Histories 2.73; Pliny, Naturalis historia 10.2; Ovid, Metamorphoses 15.392; Mela, De situ orbis 3.8; Aelian, De natura animalium 6.58; Philostratus, Vita Apollonii 3.49; Tacitus, Annales 6.28. To be sure, several of these authors question the validity of the reports concerning the bird's resurrection; nevertheless, it is clear that many in antiquity were convinced of the bird's existence. was known to roam the deserts of India; ${ }^{29}$ and, while he regards the hippocentaur as a clear fabrication, Aelian wonders if the-from his perspective-very real onocentaur, which resembles a very hairy man from the waist up and an ass from the waist down, didn't give rise to the notion. ${ }^{30}$ Phlegon of Tralles claims that a live hippocentaur was found and captured in Saune, a city in Arabia; it was first sent to Egypt, but did not survive the change in climate. There it was embalmed and sent along to the emperor in Rome, where it was exhibited in the palace. Phlegon writes that "anyone who is skeptical can examine it for himself, since as I said above it has been embalmed and is kept in the emperor's storehouse."31

Moreover, while the majority of the animal (and plant and mineral) characteristics described in the Physiologus are, from a contemporary perspective, demonstrably inaccurate, it is not correct to call them "fabulous" or "fantastic." Better are terms like "amazing” or "astonishing," inasmuch as, much like the reports in paradoxographical literature, ${ }^{32}$ there is in the Physiologus an underlying assumption that the reports are true-that they describe real animals in the real world. The contemporary reader might find, just taking one example, the notion that the panther uses its sweet breath to attract prey rather far-fetched, but this characteristic is reported matter-of-factly by Aristotle, Pliny, Plutarch and Aelian. ${ }^{33}$ Early readers of the Physiologus were likely "amazed" in the same way that contemporary audiences are amazed by an evening spent watching the cable network Animal Planet or reading National Geographic. $^{34}$

\section{Aelian, De natura animalium 16.20.}

30 Aelian, De natura animalium 17.9.

31 Phlegon of Tralles, Book of Marvels 34-35. Compare also Jerome's Vita Pauli, in which Antony, on his way to visit Paul in the desert, encounters both a centaur and a satyr. The section concludes with a report strikingly similar to Phlegon's, that is, that, lest anyone doubt that satyrs in fact exist, a live satyr had recently been displayed in Alexandria and, after its death, was preserved in salt and brought to Antioch (Jerome, Vita Pauli 8).

32 The Physiologus is often compared with paradoxography, though not always with a good understanding of the paradoxographical genre. Contrary to being patently fabulous or marvelous, paradoxographies are characterized by the frequent citation of venerable sources (above all Aristotle and Theophrastus); thus, while the goal of paradoxographical texts was clearly to amaze, and to present anecdotes that stretch believability, they present themselves as very much grounded in reality.

33 See Aristotle, Historia Animalium 8(9).6.612a; Pliny, Naturalis historia 8.62; Plutarch, De sollertia animalium 976D; Aelian, De natura animalium 5.40 .

34 Note, moreover, that some of the reports in the Physiologus are, in fact, perfectly plausible: some birds are indeed monogamous (as 
The animals in the apocryphal acts of the apostles are, in some ways, more amazing than the animals of the Physiologus, inasmuch as they sometimes speak with a human voice. But, generally speaking, the situation is much the same: while the apocryphal acts never explicitly describe or discuss the characteristics of animals, animals are typically presented enacting characteristics for which they were well known. As I have argued elsewhere (and as is, I hope, clear in the example of the wild ass), the animal episodes in the apocryphal acts assume a basic naturalhistorical knowledge of each animal's characteristics, and that knowledge is often necessary to make good sense of the animal-related episodes. ${ }^{35}$

\section{The Physiologus and the apocryphal acts of the apos- tles share a positive evaluation of the natural world}

This second common element is very much rooted in the first: it is the particular characteristics of real animals thatproperly understood-reveal the ultimate goodness of creation and its creator. The Physiologus and the apocryphal acts make the argument that nature itself is inscribed with the Christian message; the evidence for this argument is the characteristics of animals, plants and minerals. Thus, far from Schönberger's claim that, for the author of the Physiologus, it doesn't matter whether the unicorn exists or not, the real existence of these animals in nature is necessary for the argument to be persuasive. In the Acts of John, Acts of Peter, Acts of Paul, and Acts of Thomas individual animals are frequently depicted quite positively, often as recognizing and revering the apostles and modeling ideal Christian behavior in a way that surpasses the behavior of human characters in the narratives. Similarly, the Physiologus presents some animals as modeling ideal Christian behavior (e. g. the hoopoe's care of its parents; the ant's industry; the crow's monogamy, etc.).

But, for neither the Physiologus nor the apocryphal acts, is the goodness of creation evident only in the good creatures. Rather, for the careful observer-the one who really studies nature (the "physiologus," as it were)-it is clear that all of nature is inscribed with Christian meaning. While the Physiologus views nature itself, represented above all by the creatures within it and their peculiar characteristics, as a text to be interpreted, the authors of the apocryphal acts take the further step of borrowing from

Physiologus 27 and 28 report of the crow and dove); the owl is indeed active at night (c. 5); it is unclear precisely which stones are referred to in c. 37, but the notion of stones that ignite is hardly far-fetched given the existence of flint; and, of course, magnets, as in c. 38, do indeed attract iron!

35 See Spittler (2008) passim. that text, weaving those creatures and their characteristics into narratives. The underlying attitude toward the natural world-that is, as the creation of God, which holds not-so-hidden meaning for those who attend to it-is the same.

\section{The Physiologus and the apocryphal acts of the apos- tles share a strong interest in asceticism}

That both the Physiologus and the apocryphal acts advocate asceticism, particularly self-control with regard to sex, is well known. The apocryphal acts emphasize abstention from all sex, even within marriage. In the Physiologus we

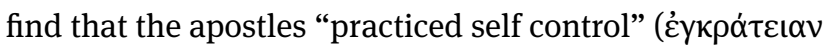

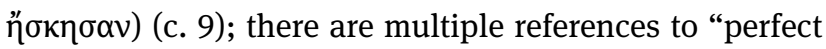

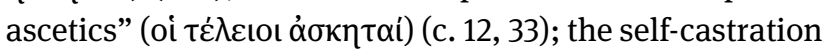
of the beaver is behavior to be imitated (at least metaphorically) (c. 23); the reader is advised to flee from the female ( $\varphi \varepsilon \tilde{y} y \varepsilon$ tò $\theta \hat{n} \lambda v$ ) so as not to be aflame with passion (c. 37); and there are warnings for those "just beginning in the life of asceticism” (

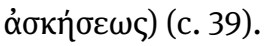

What is interesting here is the combination of the positive evaluation of the natural world-including its animalsalongside the emphasis on asceticism. This combination is a bit unusual, inasmuch as the association of the human being's base passions with animals is a commonplace in Greek literature. ${ }^{36}$ Other early Christian texts that promote asceticism did typically use animals to represent passions and temptations. Taking just one example, in Athanasius' Life of Antony we find demons assuming the forms of animals to attack the desert monk (Vita Antonii 9) as well as real animals sent by the devil to attack him (Vita Antonii 50-52). Antony does not cohabit peacefully with animals in the desert: at best he commands them and they obey, but his command is that they leave his presence. ${ }^{37}$ As Ingvild Saelid Gilhus puts it, "there was no place for animals in the new paradise that Antony had made in the desert.",38

While there are surely "bad" animals in both the apocryphal acts and the Physiologus, it is interesting to note that neither really uses animals to represent incontinent,

36 Perhaps most influential was Plato's description of the human soul as a trichotomous hybrid in the Republic 588b-589c; cf. also (and much closer to our time period) the Tabula of Cebes, where the man who has overcome his vices is described as having conquered the "greatest of beasts" (23.1-2).

37 See discussion by Gilhus (2006, 205-226).

38 Gilhus $(2006,266)$. Compare, however, Jerome's Vita Pauli, where ravens deliver rations to Antony and Paul, and two lions mourn and dig a grave for the deceased Paul. 
lustful behavior. ${ }^{39}$ In fact, in the Physiologus in particular, it is notable that even animals that elsewhere are closely associated with lust are not described in those terms. As we have already seen, the partridge is, in other Greek authors, a veritable symbol of lust, but that characteristic plays no role in c. 18 of the Physiologus. And while the report on the hyena in c. 24 does understand the animal's yearly sex change as representing a human sexual behavior to be avoided (that is, men taking the role of women in homosexual sex), there is no hint of the extreme lustiness that Clement attributes to the hyena in Paedagogus 2.10. ${ }^{40}$ The hare, perhaps the lustiest creature of all for Clement, ${ }^{41}$ does not appear in the redactio prima of the Physiologus; its treatment in the redactio secunda, moreover, makes no mention of lust, instead offering the hare's tendency to run uphill to avoid hunters (cf. Aelian De natura animalium 13.14) as an example for Christians to imitate.

Instead, and rather surprisingly, we find in the Physiologus multiple examples of animals who are, by nature, continent, if not straightforwardly ascetic: thus, the beaver, a "thoroughly gentle and quiet animal" ("ᄁ $\pi$ iov

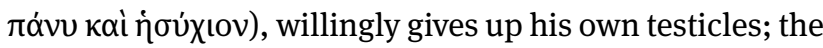
crow and the turtledove are, by nature, monogamous; the elephant has no desire for sex; and, finally, young male wild asses are essentially eunuchs-making them appropriate creatures both to be compared, in the Physiologus, with the apostles who practiced self control and to deliver, in the Acts of Thomas, an ascetic message.

\section{Conclusion}

Alan Scott has argued that, within the context of early Christian literature, the Physiologus fits best "in the wake of Origen's theology,” regarding it probable that a liter-

39 The exception among the apocryphal acts is, as noted above, the Acts of Andrew, which differs substantially from the remaining four major apocryphal acts of the apostles in precisely this regard.

40 For Clement (who like both the Physiologus and Barnabas 10.7 seems to have mistakenly understood a ban on eating hyenas in Deuteronomic law (presumably Deut 14:8) and, like the Physiologus, also cites Jer 12:9, where the hyena is indeed mentioned) the hyena is the supreme example of excessive sexual activity, having been supplied by nature with an extra organ specifically to accommodate nearly constant, non-procreative sex. See Clement's lengthy and detailed discussion in Paedagogus 2.10.

41 The hare, which Clement treats alongside the hyena (and which is in fact declared unclean in Lev 11:6 and Deut 14:7), is the hyena's nat ural counterpart, inasmuch as that animal is characterized by similar lust accompanied by nearly constant, but now procreative, sex. See Clement, Paedagogus 2.10. ary relationship existed between the two, the direction of influence and/or borrowing flowing from Origen to the Physiologus. ${ }^{42}$ While Scott acknowledges the Physiologus' "extensive parallels with paradoxography," he states that "extensive treatment of paradoxographical material in the formative years of Christian theology is unknown." ${ }^{43}$ Further, Scott writes that the Physiologus' "allegorical treatment of largely pagan (pseudo)-scientific material simply does not fit the framework of second century Christian literature." ${ }^{44}$ It is particularly this allegoricalv element that, to Scott's mind, associates the Physiologus with Origen-though he ultimately concludes that the Physiologus differs inasmuch as it "disengages allegory from the text of a canon and applies it to the natural world.” Because I rather disagree with his position, I think it's worth quoting Scott at some length:

In Origen the feeling is present that every nuance and corner of scripture is full of significance. He believed that nothing he found in the Bible had come there by accident; everything had a secret meaning. In the Physiologus, this idea is applied not so much to scripture, but to nature as a whole. The author has the idea that nature itself is filled with theological meaning which can be discerned allegorically. This idea that nature might be in terpreted in the same way as a book was not obvious to early Christian theology, and in fact a theology of the natural world was otherwise slow in developing. ${ }^{45}$

Whether or not Origen, too, viewed nature as a text to be interpreted is itself, I think, debatable. ${ }^{46}$ The key point for the present purposes, however, is that this is exactly what

42 Scott $(1998,440-441)$. Scott argues that "Origen frequently refers to pagan zoological/paradoxographical material, and in doing so he normally relies on pagan sources, not on Christian sources, and certainly not on a primitive work like the Physiologus. That a Christian in Egypt might use Origen is easy to believe; that Origen might use a book like the Physiologus is doubtful” (440).

$43 \operatorname{Scott}(1998,439)$. While it is unclear what exactly what date range is intended in the phrase "formative years," I would note that at the end of the second century Clement of Alexandria was rather deeply engaged with paradoxographical material, being-just as one example-our earliest confirmed reader of one of the earliest paradoxographical texts, Apollonius' Amazing Stories. Clement reproduces, without citation, Amazing Stories 46, a discussion of the Pythagorean prohibition on eating beans. See discussion in my forthcoming edition, translation and commentary on Apollonius' Amazing Stories (in FGrHist).

$44 \operatorname{Scott}(1998,440)$.

45 Scott $(2002,86)$.

46 Compare, for example, Cox Miller, who draws just the opposite conclusion: "This view of the natural world as a potentially explosive cache of theological realities was developed in a Christian context by the Alexandrians Clement and Origen, both of whom considered meditations on phusis to be a way of initiation into the sensuous enig- 
the Physiologus has in common with the apocryphal acts of the apostles.

The Acts of John, Acts of Peter, Acts of Paul, and Acts of Thomas have used contemporary natural historical information on animals, similar-if not identical-to what we find in Aristotle, Philo, Pliny, Aelian, the various paradoxographers and the Physiologus, to construct narrative episodes in which the known characteristics of real animals play central roles. ${ }^{47}$ I have already discussed how I see this happening in act eight of the Acts of Thomasand that is, in fact, one of the clearest examples of the phenomenon-but there are many others: the obedient bedbugs, the snake, and the partridge in the Acts of John; the snake in the Acts of Thomas; the talking dog in the Acts of Peter; and the multiple lions in the Acts of Paul.

Elsewhere, I have concluded that one of the interests evident in the depiction of animals in the Acts of John, Acts of Peter, Acts of Paul, and Acts of Thomas "is to underscore the goodness of creation and its creatures and to emphasize, against those who espouse a wicked biblical demiurge, that it is the product of God." ${ }^{48}$ I still think that is basically right, and I think it makes good sense if our typical dating of these texts (that is, as composed between the mid second and mid third centuries) is correct; this seems like a good time for Christians, perhaps especially ascetic Christians, to make a positive argument for the goodness of creation and its creator. Was that also a good time for the Physiologus to have been composed? Here I offer a resounding maybe. I would not, on the basis of the evidence presented here, argue against a late third or fourth century date for the Physiologus, but I certainly do not think the second century can be excluded on the basis of the religious and intellectual milieu, as Scott does. The evidence provided by comparison with the apocryphal acts suggests, instead, a date of composition allowing for both familiarity with the Thecla narrative and the possible usage of the Physiologus by the author of the Acts of Thomas, that is, a date somewhere between the last quarter of the second century and first half of the third. To reiterate: I do not think the evidence gleaned from the apocryphal acts makes a conclusive case, but I do think it indicates the plausibility of such a date.

One final point: the interest in the natural world present in both the Physiologus and the apocryphal acts is, I would wager, not exclusive to these texts. To the contrary, I suspect that the more we work with the Physiologus-in

mas of the spirit. Nature was a symbolic language, a theological text" (2001, 64-65).

47 See Spittler (2008).

48 Spittler (2008, 231). its straightforward and very obvious interest in the natural world-and the more familiar it becomes to scholars of early Christian literature, the more we will see that a wide variety of early Christian authors were reflecting on the natural world in interesting ways. I look forward to seeing what we will learn, once the Physiologus (along with Aelian, and Pliny the Elder, and paradoxography, etc.) becomes basic reading for scholars of the New Testament and early Christian literature. My intuition is that we will find an early Christianity very much engaged in debates about the natural world and the Christian's place within it.

\section{Bibliography}

Castelli, Elizabeth. 2004. Martyrdom and Memory: Early Christian Culture Making. New York: Columbia University Press. Cox Miller, Patricia. 2001. The Poetry of Thought in Late Antiquity: Essays in Imagination and Religion. Burlington: Ashgate.

Gilhus, Ingvild Saelid. 2006. Animals, Gods and Humans: Changing Attitudes to Animals in Greek, Roman and Early Christian Thought. New York: Routledge.

Junod, Eric, and Jean-Daniel Kaestli, Eds. 1983. Acta Iohannis. CCSA 1. Turnhout: Brepols.

Kaimakis, Dimitris, Ed. 1974. Der Physiologus nach der ersten Redaktion. Meisenheim am Glan: A. Hain.

Lipsius, Richard A. 1883. Die apokryphen Apostelgeschichten und Apostellegenden: Ein Beitrag zur altkirchlichen Literaturgeschichte. Vol. 1. Braunschweig: C. A. Schwetschke und Sohn.

Perry, Ben E. 1941, “Physiologus.” PRE 20,1:1074-1129.

Peterson, Erik. (1954) 1959. “Die Spiritualität des griechischen Physiologos.” In Frühkirche, Judentum und Gnosis: Studien und Untersuchungen, ed. by Erik Peterson, 236-253. Rom: Herder (= Byzantinische Zeitschrift 47:60-72).

Schneider, Horst. 2001. “Thekla und die Robben.” Vigiliae Christianae 55:45-57.

Schneider, Horst. 2002a. “Das Ibis-Kapitel im Physiologus.” Vigiliae Christianae 56:151-164.

Schönberger, Otto. (2001) 2014. Physiologus: Griechisch/Deutsch. Stuttgart: Reclam.

Scott, Alan. 1998. “The Date of the Physiologus.” Vigiliae Christianae 52:430-441.

Scott, Alan. 2002. "Zoological Marvel and Exegetical Method in Origen and the Physiologus." In Reading in Christian Communities: Essays on Interpretation in the Early Church. Christianity and Judaism in Antiquity 14, ed. by Charles A. Bobertz and David Brakke, 80-89. Notre Dame, IN: University of Notre Dame Press).

Spittler, Janet. 2008. Animals in the Apocryphal Acts of the Apostles: The Wild Kingdom of Early Christian Literature. WUNT 2.247. Tübingen: Mohr Siebeck. 
Spittler, Janet. Forthcoming. “Apollonios, Amazing Stories (1672).” In Die Fragmente der Griechischen Historiker. Part IV, ed. by Stefan Schorn (2011-) and Guido Schepens (1998-2010). Leiden: Brill. First published online in April 2016 http://dx.doi. org/10.1163/1873-5363_jciv_a1672.

Treu, Ursula. 1966. "Zur Datierung des Physiologus.” ZNW 57:101104.

Treu, Ursula. 1993. "The Physiologus and the Early Fathers.” In Studia Patristica. Vol. 24, Papers presented at the Eleventh International Conference on Patristic Studies held in Oxford 1991, ed. by Elizabeth A. Livingstone, 197-200. Leuven: Peeters.
Wellmann, Max. 1930. "Der Physiologos: Eine religionsgeschichtlich-naturwissenschaftliche Untersuchung." Philologus: Zeitschrift für das klassische Altertum; Supplementband 22,1:1-116. 
